\title{
Geothermal and radioactive heat studies of parts of southern Bida basin, Nigeria and the surrounding basement rocks
}

\author{
John U. Megwara ${ }^{1}$, Emmanuel E. Udensi ${ }^{2}$, Peter I. Olasehinde ${ }^{2}$, Mohammed A. Daniyan ${ }^{3}$ \& Kolawole M. Lawal ${ }^{4}$ \\ ${ }^{1}$ Nigerian Geological Survey Agency, P.M.B. 2007, Kaduna, Nigeria \\ ${ }^{2}$ Federal University of Technology, P.M.B.65, Minna, Nigeria \\ ${ }^{3}$ Ibrahim Badamasi Babangida University, Lapai, Nigeria \\ ${ }^{4}$ Ahmadu Bello University, Zaria, Nigeria \\ *Corresponding author E-mail: megwarauj@yahoo.com
}

\begin{abstract}
Aeromagnetic and aeroradiometric data covering parts of southern Bida basin, Nigeria and the surrounding basement rocks were processed and interpreted. The research covered both basin and basement rock sections, and was aimed at determining the geothermal heat flow and radioactive heat characteristics of the survey area. The number of data points used for analysis were 2,937, obtained from the digitization of eleven $1 / 2$ degrees by $1 / 2$ degrees contour maps. Data processing methods used in the study include determination of heat from radiometric data, regional-residual separation of the total magnetic intensity data, determination of depth-to-top and depth-to-bottom of magnetic sources and estimation of field scaling exponent using the Fractal technique. The research results gave geothermal heat flow values ranging from $69.167 \mathrm{mWm}^{-2}$ to $124.821 \mathrm{mWm}^{-2}$ with an average value of $90.959 \mathrm{mWm}^{-2}$ and radioactive heat values ranging from 0.91 to $4.53 \mu \mathrm{W} / \mathrm{m}^{3}$ with an average value of $2.28 \mu \mathrm{W} / \mathrm{m}^{3}$. Deductions made from the survey are, the field scaling exponent varies linearly with depth of downward continuation and Katakwa is a prospect area for geothermal heat.
\end{abstract}

Keywords: Basement, basin, fractal, magnetics, radiometrics.

\section{Introduction}

In recent years, combined airborne magnetic and radiometric surveys have been used as geological mapping tools, unless transported cover or abundant surface water render the radiometric data of little use. Airborne magnetic and radiometric data can be manipulated in a variety of ways, to minimize noise, enhance particular aspects of the data and integrate with other geoscience and geographic data. Typically, the ultimate goal is to produce an interpretation focusing on one or more particular problems that provides a reasonable and accurate depiction of geology. These problems include: provision of the third dimension to surface mapping and sampling, delineation of structures and alteration under a cover of overburden or water, geothermal exploration, research on radioactive heat, hydrocarbon survey, magnetic and radiometric minerals investigation using cost effective airborne measurements. Recent works by Nwankwo et al. [20] and Nwankwo et al. [21] have shown great potential for geothermal heat flow in the Bida basin. Hence, this study involves the interpretation of aeromagnetic and aeroradiometric data so as to determine the geothermal heat flow and radioactive heat features of the study area.

\section{Geology of the study area}

The study area is shown in Figure 1, it is bounded by longitudes $4.5^{\circ} \mathrm{E}$ to $8.0^{\circ} \mathrm{E}$ and latitudes $8.0^{\circ} \mathrm{N}$ to $9.0^{\circ} \mathrm{N}$, and has an areal extent of about $33,275 \mathrm{~km}^{2}$. The geology of the study area is shown in Figure 2; marked out in black outline. The southern Bida basin section of the study area; forms part of the larger Bida basin. The successions in the southern Bida basin consist of the basal Lokoja Formation, overlain by the Patti Formation and capped by the Agbaja Formation. The basal Lokoja Formation is a sequence of matrix supported conglomerates and sandstones overlying the PreCambrian to lower Paleozoic basement. Depositional environments are predominantly within fluvial systems of a continental setting. The Patti Formation consists of dark grey carbonaceous shales; mudstones and siltstones 
representing flood plains to shallow marine deposits with likely organic rich intervals. The overlying Agbaja Formation is made up of ferruginised oolitic and kaolinitic mudstone of a marginal environment [1]. The surrounding PreCambrian basement rocks consist of a suit of Pre-Cambrian gneisses, migmatites and metasedimentary schist crosscut by intrusive granitoids [30]. The Pre-Cambrian basement rocks experienced severe deformation during the late PanAfrican phase (600 m.y.), and developed megashears that were reactivated during the late Campanian-Maastrichtian [5]. The gneisses and metasedimentary schist are found mostly as flat lying outcrops [30].

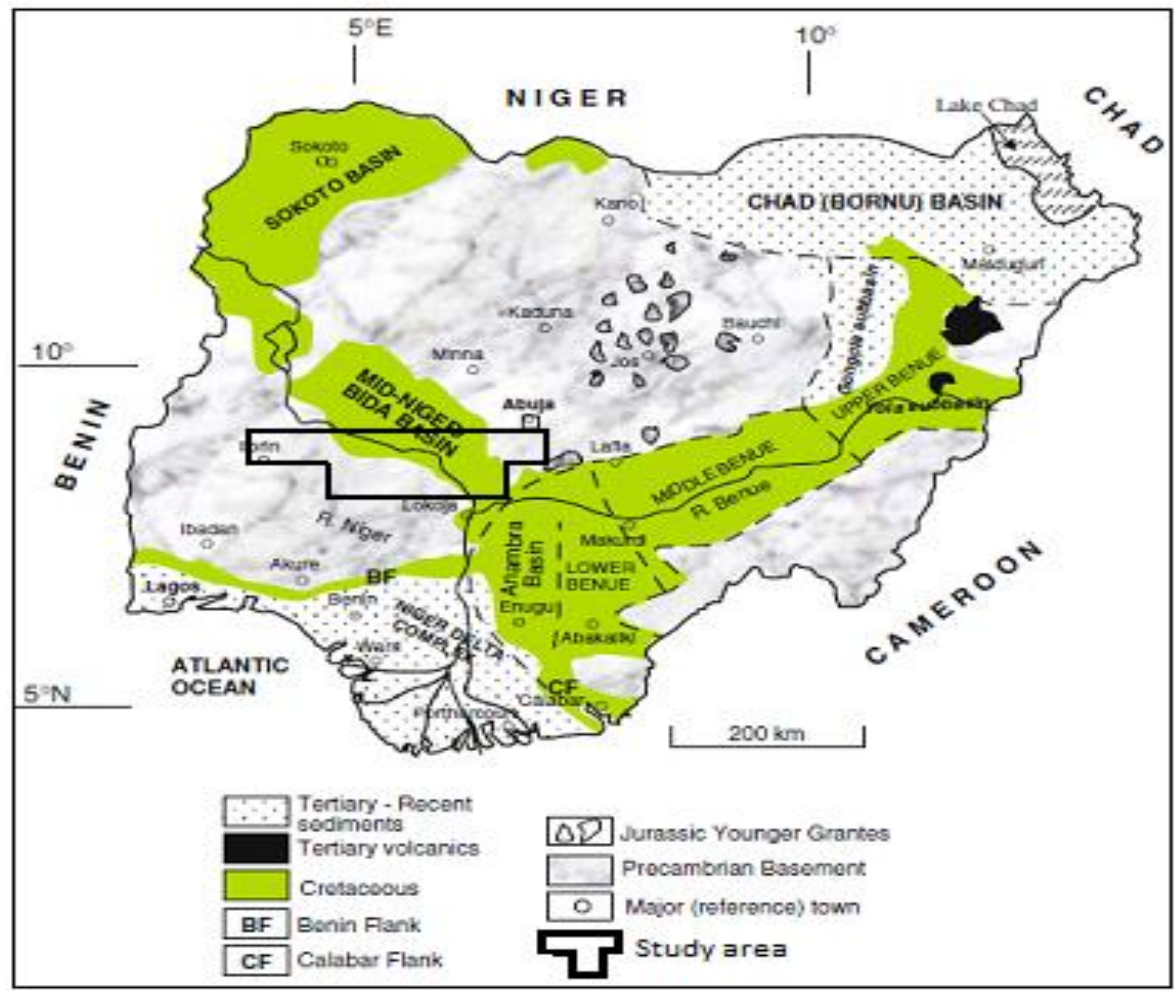

Fig. 1: Geological Map of Nigeria showing the study area in black outline (Source: [22])

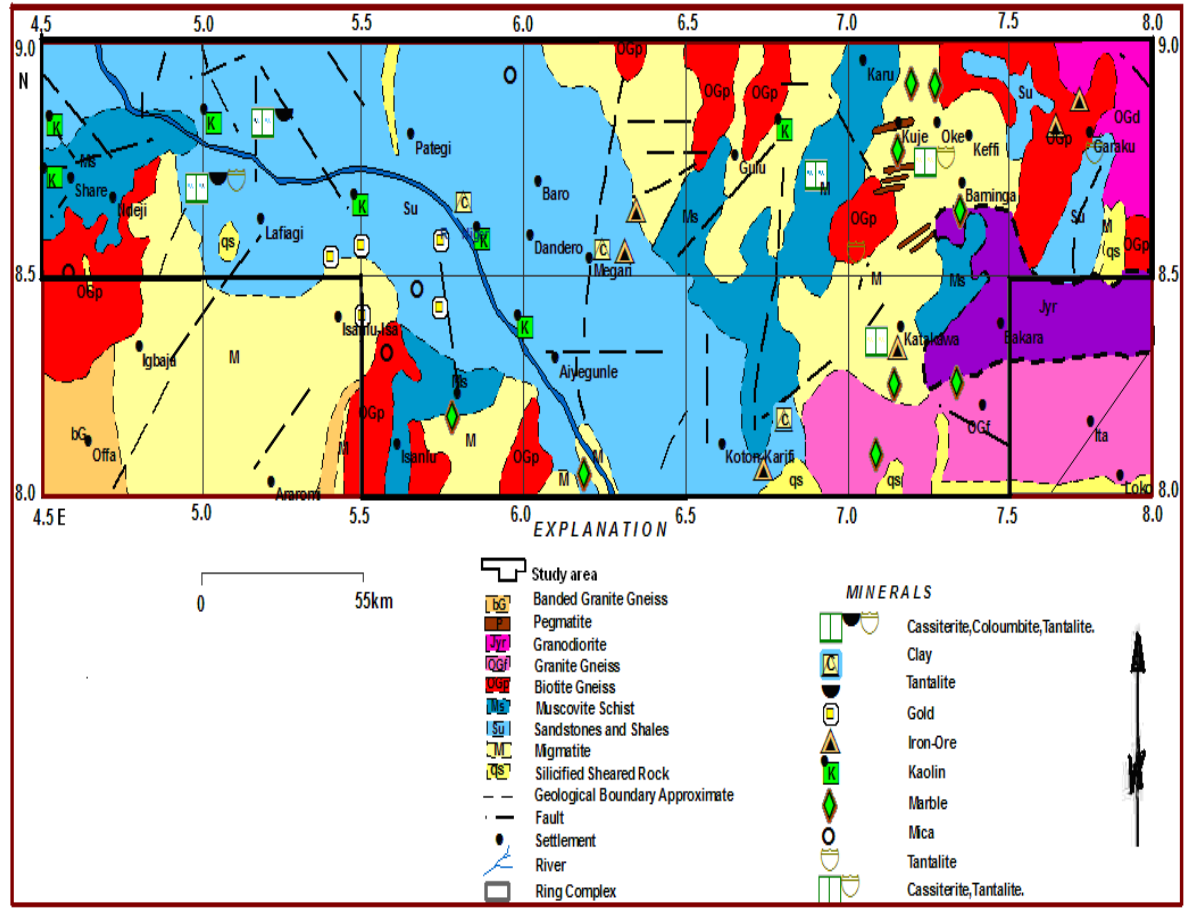

Fig. 2: Geological and Mineral map of the study area (Adapted from the Geological and Mineral Map of Nigeria, 2009, Nigerian Geological Survey Agency). 


\section{Materials and methods}

\subsection{Materials}

Magnetic data acquisition: The study area is made up of 11 aeromagnetic maps acquired from the Nigerian Geological Survey Agency. These are numbers: 202-208 and 225-228. The magnetic information consists of profiles or flight lines plotted on continuous strip chart. The aeromagnetic data was collected at a nominal flight altitude of $152.4 \mathrm{~m}$ along north-south flight lines spaced approximately $2 \mathrm{~km}$ apart. The airbourne survey data were published in the form of $1 / 2$ degrees by $1 / 2$ degrees contour maps of total magnetic intensity on a scale of 1:100,000. The magnetic data was obtained from digitization of the total magnetic intensity contour maps at an interval of 0.0271 units $(\approx 3 \mathrm{~km})$ yielding 2,937 data points for the 11 sheets. The $3 \mathrm{~km}$ grid interval imposed a Nyquist frequency of $0.167 \mathrm{~km}^{-1}$.

Radiometric data acquisition: Airborne radiometric data was obtained from the Nigerian Geological Survey Agency (NGSA), which carried out airborne radiometric survey of Nigeria between the years 2002-2009. The data acquired from the airborne survey was presented in digital form as a composite grid of 1:100000 sheets covering the entire nation. The radiometric data were acquired at a flying height of $80 \mathrm{~m}$, emphasizing high resolution survey. Line spacing and Tie line spacing were $500 \mathrm{~m}$ and 5,000 m respectively. A line direction of 135/315 degrees was adopted for the survey. The radiometric data for this study was obtained by windowing out 11 radiometric sheets covering the study area, for qualitative analysis and interpretation.

\subsection{Data processing methods}

Magnetic Data Processing

Regional-residual separation: The regional anomaly was removed from the observed data using the Robust Polynomial Fitting method. The research area does not have complex geology and it has spatial extent, thus, it seemed plausible to assume that the regional field is a first-order polynomial surface. Residual magnetic field data was obtained as the deviations of the fitted plane surface from the total magnetic intensity.

Fractal-depth technique: The Spector and Grant [32] method relates average depth to source to rate of decay of the magnetic power spectra. This method, which assumes a uniform distribution of parameters for an ensemble of magnetized blocks, leads to a depth dependent exponential rate of decay. Fedi et al. [9] showed that also inherent in the model is a power law rate of decay that is independent of depth. Thus, for most cases, except for extreme depths and some block sizes, the observed power spectrum should be corrected for a power decay rate of $\beta \sim 3$. $\beta$ is the decaying exponent. This power law decay rate is similar to the scaling behaviour supposed as a fractal character, of observed residual magnetic fields.

Fractal geophysics supposes that many geophysical data sets have power law spectra. These include surface gravity and magnetics. Similarly, Fractal geology; supposes that many geological phenomena are scale invariant, examples include frequency size distribution of rock fragments, faults, earthquakes, volcanic eruptions, mineral deposits and oil fields. Fractal distributions are used as a means of quantifying self-similar dispersions. A fractal distribution requires that the number of objects larger than a specified size has a power law dependence on the size [37].The essential feature of a fractal is the existence of a similar structure at all length of scales. This is because the spatial variation of most geophysical parameters such as density and susceptibility often look similar at a wide range of scale; they can therefore be described using fractals $[2,33,13,8,11,36]$.

Maus and Dimri [16] used the fractal method and modeled the sources of the potential field by a random function with scaling properties, defined on a half space with its top at a specified depth beneath the observation plane. This model has been shown by Maus and Dimri [17] not to produce reliable depth results when applied to real data. Maus and Dimri [17] observed that the theoretical power spectrum for a basin with source free sediments falls off rapidly at high frequency whereas the power spectra of real data tend to have flat tails. According to Pilkington and Todoeshcuck [26], the process of downward continuation corrects for the difference between the power spectra observed at the survey height and that at the ground. When magnetic data are continued downwards, the depth at which the power spectrum flattens out, termed the white depth can be taken as estimate of the depth to the magnetic source distribution [12]. This is equivalent to the depth evaluation procedure for an ensemble of magnetic sources introduced by Spector and Grant [32]. If survey height $h=0$, the power spectrum becomes constant, under the assumption of uncorrelated magnetization values, and have a magnetization power spectra that is flat or white.

Thus, if a non-magnetic sedimentary stratum overlies a more magnetic crystalline basement, the depth to basement can be calculated from aeromagnetic data by using this method. The results obtained by Hahn et al. [12] indicated that the spectrum becomes flat only when some sort of correlation in magnetization was assumed. The source scaling exponent $\gamma$ reflects the degree of correlation in magnetization in a fractal model [15, 25-26]. 
when $\gamma=0$

We have white noise, where values of magnetization are uncorrelated.

when $\gamma>0$

The values are anti-correlated in that successive values are likely to have opposite signs.

when $\gamma<0$

The values are correlated to a degree that increases with decreasing $\gamma$.

Pilkington et al. [24] have shown that a correlated fractal model $(\gamma<0)$, of the crustal magnetization distribution is preferred over the standard assumption of independent, spectrally white magnetization distribution $(\gamma=0)$.

The present study utilizes a fractal-depth method which enables the prediction of the value of scaling exponents at the source level without prior knowledge of the source depth. The method is applied to the 22 fractal subsections covering the study area, shown in Table 1 . The residual magnetic field data for each subsection was continued downwards nine levels from $0.5 \mathrm{~km}$ down to $4.5 \mathrm{~km}$ at $0.5 \mathrm{~km}$ interval. At each of these levels the magnetic field scaling exponent $\beta$ is determined by plotting log power against log frequency $[26,11]$.

The scaling exponent of the source is obtained by using the method of Maus and Dimri [15] and Lawal et al. [13]:

$\gamma=\beta+1$

where

$\beta=$ scaling exponent of the field

$\gamma=$ scaling exponent of the source

Applying a linear equation format and incorporating the depth of downward continuation, this gives

$\gamma=\mathrm{qd}+\mathrm{r}$

where

$\mathrm{d}=$ depth of downward continuation

$\mathrm{r}$ and $\mathrm{q}$ are constants

Table 1: 22 fractal subsections covering the study area

\begin{tabular}{ccccc}
\hline Subsection & Sheet name & $\begin{array}{c}\text { Sheet } \\
\text { number }\end{array}$ & $\begin{array}{c}\text { Longitude } \\
\text { (Decimal degrees) }\end{array}$ & $\begin{array}{c}\text { Latitude } \\
\text { (Decimal degrees) }\end{array}$ \\
\hline 1 & Share & 202 & $4.50-4.75$ & $8.50-9.00$ \\
2 & Share & 202 & $4.75-5.00$ & $8.50-9.00$ \\
3 & Lafiagi & 203 & $5.00-5.25$ & $8.50-9.00$ \\
4 & Lafiagi & 203 & $5.25-5.50$ & $8.50-9.00$ \\
5 & Pategi & 204 & $5.50-5.75$ & $8.50-9.00$ \\
6 & Pategi & 204 & $5.75-6.00$ & $8.50-9.00$ \\
7 & Baro & 205 & $6.00-6.25$ & $8.50-9.00$ \\
8 & Baro & 205 & $6.25-6.50$ & $8.50-9.00$ \\
9 & Gulu & 206 & $6.50-6.75$ & $8.50-9.00$ \\
10 & Gulu & 206 & $6.75-7.00$ & $8.50-9.00$ \\
11 & Kuje & 207 & $7.00-7.25$ & $8.50-9.00$ \\
12 & Kuje & 207 & $7.25-7.50$ & $8.50-9.00$ \\
13 & Keffi & 208 & $7.50-7.75$ & $8.50-9.00$ \\
14 & Keffi & 208 & $7.75-8.00$ & $8.00-8.50$ \\
15 & Isanlu & 225 & $5.50-5.75$ & $8.00-8.50$ \\
16 & Isanlu & 225 & $5.75-6.00$ & $8.00-8.50$ \\
17 & Aiyegunle & 226 & $6.00-6.25$ & $8.00-8.50$ \\
18 & Aiyegunle & 226 & $6.25-6.50$ & $8.00-8.50$ \\
19 & Koton karifi & 227 & $6.50-6.75$ & $8.00-8.50$ \\
20 & Koton karifi & 227 & $6.75-7.00$ & $8.00-8.50$ \\
21 & Katakwa & 228 & $7.00-7.25$ & $8.00-8.50$ \\
22 & Katakwa & 228 & $7.25-7.50$ & \\
\hline
\end{tabular}


Depth-to-bottom of magnetic sources: Several methods have been proposed to provide an assessment of crustal temperatures from magnetic anomalies. Such methods typically assume that the depth extent of crustal magnetic sources corresponds to the Curie temperature; the temperature at which rocks lose their spontaneous magnetization (e.g., $580{ }^{\circ} \mathrm{C}$ for magnetite). These methods usually operate in the Fourier domain by analyzing the shape of the power spectrum calculated from aeromagnetic anomalies [32], and they depend on assumptions about the distribution of crustal magnetization [9, 27]. Early methods assumed that crustal magnetization is a random function of position characterized by a flat power density spectrum [7, 4, 34, 28]. However, other studies have suggested that crustal magnetization follows fractal behavior; e.g., [24, 16-17, 14, 23, 10].

The method used in the present study is derived from the technique developed by Maus et al. [18] and modified by Bouligand et al. [6] which incorporates a model of fractal random magnetization, thus providing a representation for crustal magnetization. According to Bouligand et al. [6], mapping depth to the Curie temperature isotherm from magnetic anomalies in an attempt to provide a measure of crustal temperatures are based on the estimation of the depth to the bottom of magnetic sources. The Curie temperature isotherm is assumed to correspond to the temperature at which rocks lose their spontaneous magnetization.

Thus, according to Maus et al. [18], Magnetic anomalies are assumed to be measured on a horizontal plane at an elevation $z_{t}$ above magnetic sources. Magnetic sources are assumed to reside within a horizontal slab of thickness $\Delta z$, with magnetization oriented parallel or antiparallel to the geomagnetic field. Magnetization is thus assumed to be a random function of position $(\mathrm{x}, \mathrm{y}, \mathrm{z})$, with a power spectrum proportional to the norm of the wave number raised to power $-\beta$ (fractal parameter or field scaling exponent). Hence, Bouligand et al. [6] and Maus et al. [18] suggested that magnetization has a fractal distribution defined by three independent parameters: the depths to the top and bottom of magnetic sources and a fractal parameter $\beta$ related to the geology.

The fractal parameter $\beta$, which is the slope of the power spectrum in a log-log scale, is related to the geology and thus might vary geographically depending on rock types or geologic structures. With these assumptions, the magnetic sources can be fully described by three unknowns: the depth to the top of magnetic sources $\mathrm{z}_{\mathrm{t}}$, the thickness of magnetic sources $\Delta z$, and the fractal parameter $\beta[6]$.

Assuming a constant value of $\beta=4$, Maus et al. [18]; the depth to the bottom of magnetic sources $\mathrm{z}_{\mathrm{b}}$ is deduced from the depth to the top $\left(\mathrm{z}_{\mathrm{t}}\right)$ and the thickness $(\Delta \mathrm{z})[6]$.

$\mathrm{z}_{\mathrm{b}}=\mathrm{z}_{\mathrm{t}}+\Delta \mathrm{z}$

Geothermal heat flow: Temperature in the Earth is one of the most important parameters in models for the constitution and active tectonics of the crust [3]. A boundary condition on temperature at depth in the continental crust can be used to map the Curie isotherm where it forms the base of magnetic crust. At the Curie temperature, a substance loses magnetic polarization. Consequently, it may be possible to locate a point on the isothermal surface by determining the depth to the bottom of a polarized rock mass. If enough depths can be determined, an isothermal surface at the Curie temperature can be defined [19].

The depth to the bottom of magnetic sources is also called the Curie point depth. From the estimate of depth to the bottom of magnetic sources, a map of the Curie point isotherm can be produced. Using measurements of Curie temperatures and information about thermal conductivity of the rock, a map for the distribution of heat flow can also be produced. From the Curie point depths, the heat flow can be obtained by the expression [19].

$\mathrm{Q}=\mathrm{k} \partial \mathrm{T} / \partial \mathbf{z}$

Where $\mathrm{mWm}^{-2}$ is the unit of Q in SI system. In equation (4); $\mathrm{k}$ is the thermal or heat conductivity, $\mathrm{T}$ is the average Curie temperature and $\mathrm{z}$ is the Curie depth of the domain. For this survey, Curie temperature ' $\mathrm{T}$ ' is taken as $580{ }^{\circ} \mathrm{C}$ and $\mathrm{k}$ is the thermal conductivity taken as $1.8 \mathrm{Wm}^{-1} \mathrm{C}^{-1}$ [31].

Radiometric Data Processing

Radioactive Heat Analysis: According to Salem and Fairhead [29], radioactive heat production from radiometric data is given by the expression:

$\mathrm{A}\left(\mu \mathrm{W} / \mathrm{m}^{3}\right)=\rho\left(0.0952 \mathrm{C}_{\mathrm{u}}+0.0256 \mathrm{C}_{\mathrm{Th}}+0.0348 \mathrm{C}_{\mathrm{k}}\right)$ 
Where,

$\mathrm{A}=$ radioactive heat

$\rho=$ density of rock adapted from Telford et al. [35]

$\mathrm{C}_{\mathrm{u}}, \mathrm{C}_{\mathrm{Th}}$ and $\mathrm{C}_{\mathrm{k}}$ are the concentrations of Uranium, Thorium and Potassium respectively.

The concentration of the three radiometric elements is read from the radiometric map covering the 22 subsections adopted for magnetic data processing. The value of the radiometric element's concentration is applied in equation (5) to compute the radioactive heat for the respective subsection.

\section{Results and analysis}

The total magnetic intensity (TMI) map of the study area is shown in Figure 3. The general trending fabric of the TMI anomalies is the northeast-southwest direction. The regional magnetic field map (Figure 4) shows contour lines trending in a general northwest-southeast direction. The residual magnetic field map (Figure 5) shows a general trending fabric of northeast-southwest direction similar to those of the TMI map (Figure 3). To obtain the values for $\gamma$, $\beta$ and depth-to-the top of magnetic sources $z_{t}$; a Fortran programme, Fractal; was applied to the downward continued data of the 22 subsections. The field scaling exponent varies linearly with depth of downward continuation (Figure 6 ).

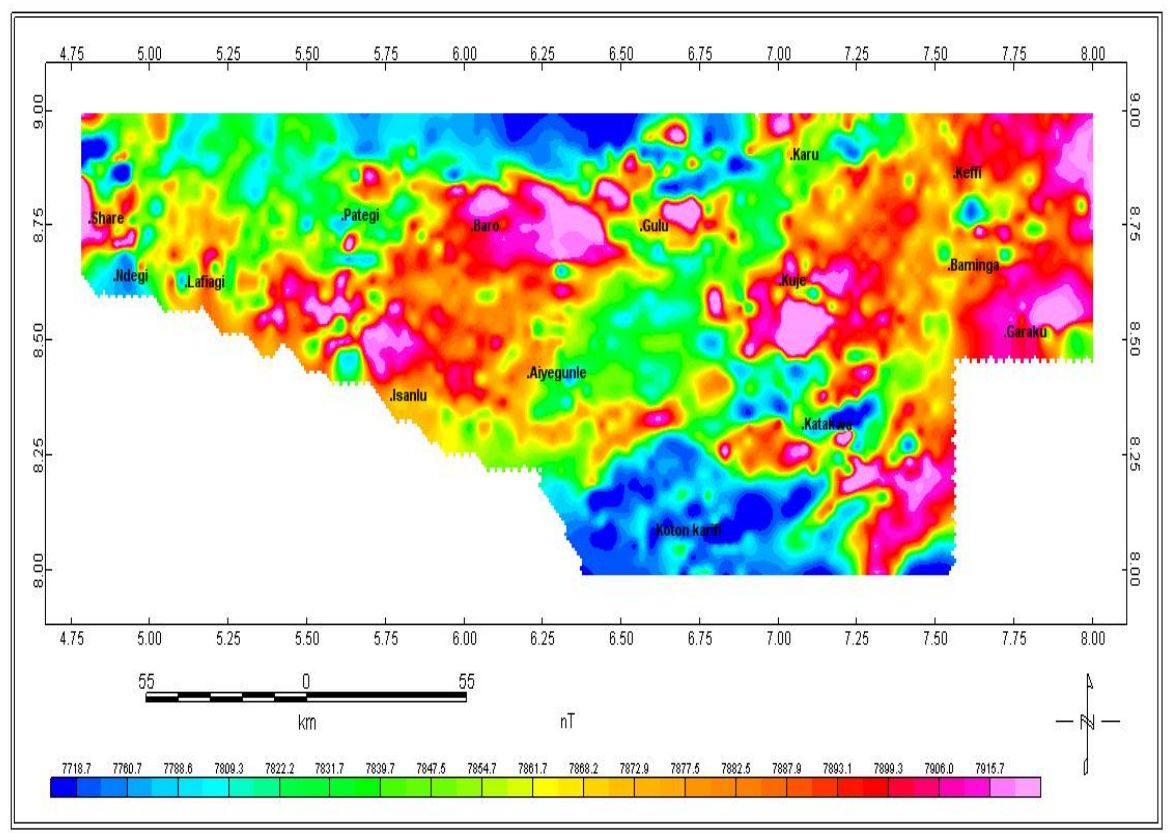

Fig. 3: Total magnetic intensity

The summary of depth-to-top of magnetic sources $z_{t}$ for all the subsections is shown in Table 2 . The values of $z_{t}$ ranges from $0.022 \mathrm{~km}$ to $3.88 \mathrm{~km}$ with an average value of $1.299 \mathrm{~km}$. The highest value of $\mathrm{z}_{\mathrm{t}}(3.88 \mathrm{~km})$ is observed in subsection 4. While the lowest value of $\mathrm{z}_{\mathrm{t}}(0.022 \mathrm{~km})$ is observed in subsection 21 . 


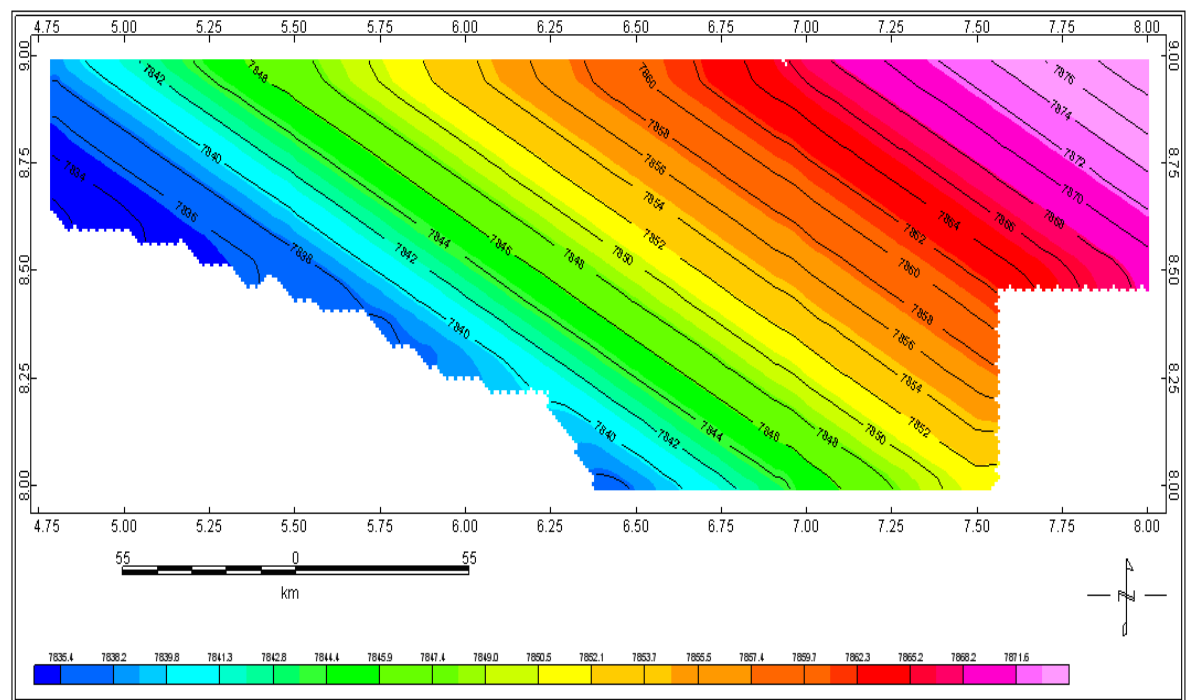

Fig. 4:. Regional magnetic field. Contour interval $=2$ nano tesla.

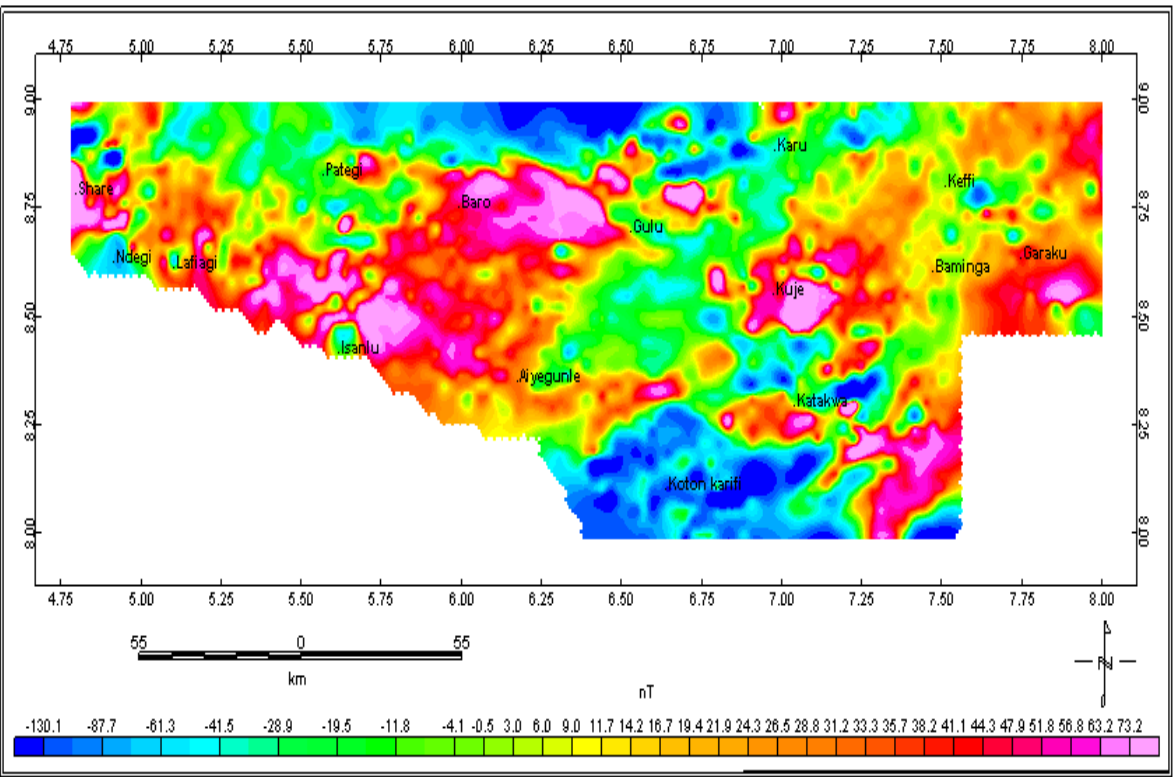

Fig. 5: Residual magnetic field

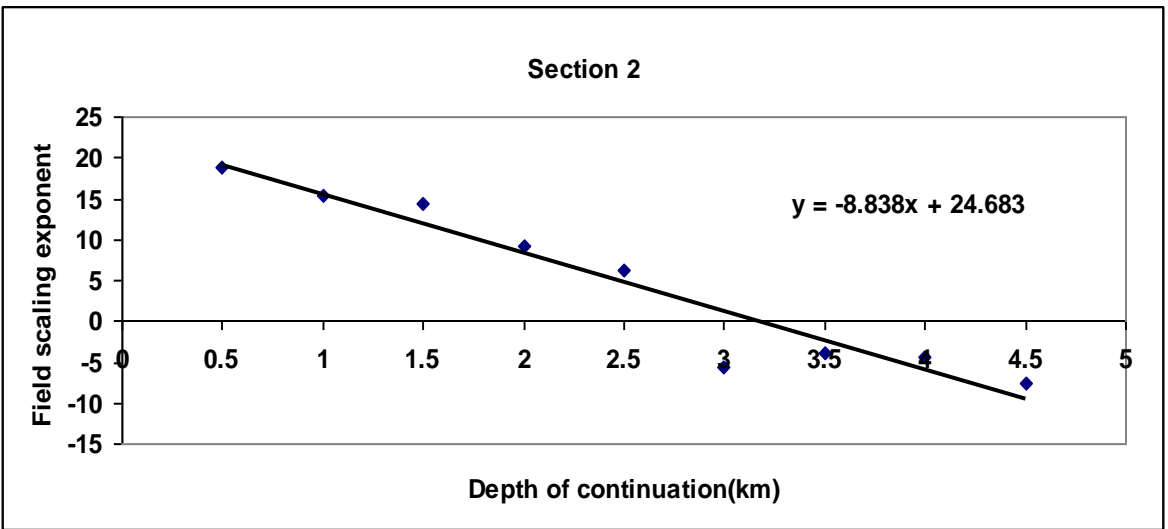

Fig. 6: Sample plot of variation of $\beta$ (field scaling exponent) with depth of downward continuation $(0.5 \mathrm{~km}-4.5 \mathrm{~km})$. 
Table 2: Summary of the results for the depth-to-top of magnetic sources and the source scaling exponent $\gamma$ for the 22 fractal subsections.

\begin{tabular}{|c|c|c|c|c|}
\hline Subsection & $\begin{array}{c}\text { Longitude } \\
\text { (Decimal } \\
\text { degrees) }\end{array}$ & $\begin{array}{c}\text { Latitude } \\
\text { (Decimal } \\
\text { degrees) }\end{array}$ & $\begin{array}{c}\text { Depth to top of magnetic } \\
\text { source }(\mathrm{km})\end{array}$ & $\begin{array}{c}\text { Source scaling exponent } \\
\qquad \gamma\end{array}$ \\
\hline 1 & 4.625 & 8.75 & No data & No data \\
\hline 2 & 4.905 & 8.75 & 2.510 & 3.500 \\
\hline 3 & 5.125 & 8.75 & 3.400 & 1.541 \\
\hline 4 & 5.375 & 8.75 & 3.880 & 2.226 \\
\hline 5 & 5.625 & 8.75 & 2.642 & 2.440 \\
\hline 6 & 5.875 & 8.75 & 1.620 & 2.610 \\
\hline 7 & 6.125 & 8.75 & 1.020 & 2.930 \\
\hline 8 & 6.375 & 8.75 & 0.568 & 1.907 \\
\hline 9 & 6.625 & 8.75 & 0.085 & 3.632 \\
\hline 10 & 6.875 & 8.75 & 0.038 & 3.809 \\
\hline 11 & 7.125 & 8.75 & 0.044 & 3.579 \\
\hline 12 & 7.375 & 8.75 & 0.076 & 3.765 \\
\hline 13 & 7.625 & 8.75 & 0.114 & 3.588 \\
\hline 14 & 7.875 & 8.75 & 0.065 & 3.744 \\
\hline 15 & 5.625 & 8.25 & 0.625 & 2.641 \\
\hline 16 & 5.875 & 8.25 & 1.244 & 1.686 \\
\hline 17 & 6.125 & 8.25 & 3.715 & 2.087 \\
\hline 18 & 6.375 & 8.25 & 3.468 & 3.320 \\
\hline 19 & 6.625 & 8.25 & 1.820 & 3.017 \\
\hline 20 & 6.875 & 8.25 & 0.225 & 2.200 \\
\hline 21 & 7.125 & 8.25 & 0.022 & 2.462 \\
\hline 22 & 7.375 & 8.25 & 0.092 & 2.237 \\
\hline
\end{tabular}

Figure 7 shows shallow depth-to-top of magnetic sources at Isanlu, Kuje, Gulu, Karu, and Katakwa (basement rock section). While high values of $z_{t}$ are observed at Aiyegunle, Lafiagi and Pategi (basin areas). The surface relief map of $z_{t}$, Figure 8 shows a fold pattern depicting the basement rock relief.

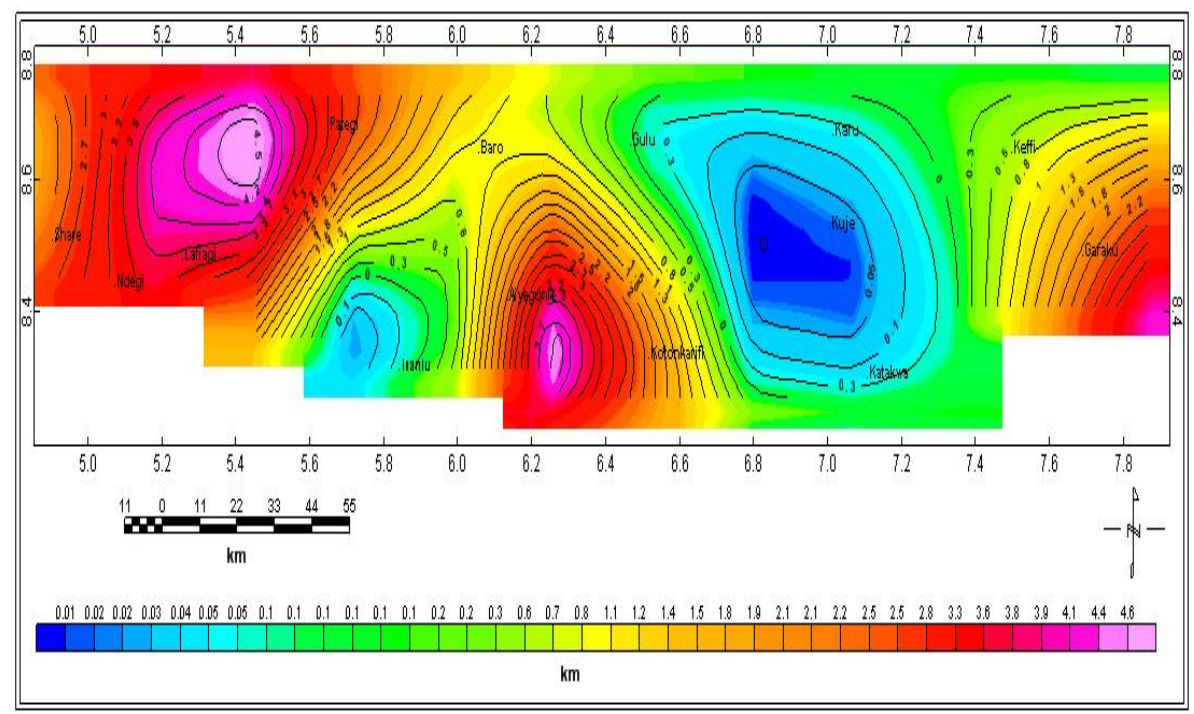

Fig. 7: Fractal depth-to-top of magnetic sources. Contour interval $=0.01 \mathrm{~km}$.

Depth-to-bottom of magnetic sources $\left(Z_{b}\right)$ : Table 3 shows the results obtained for $Z_{b}$ (depth-to-bottom of magnetic sources), $\Delta z$ (thickness of anomaly within the crust) and geothermal heat flow (Q). The values of $Z_{b}$ ranges from 8.364 $\mathrm{km}$ to $15.094 \mathrm{~km}$ with an average value of about $11.837 \mathrm{~km}$. Figure 9 shows coloured representation of depth-to-bottom of magnetic sources. It indicates high values of $Z_{b}$ around Pategi and Aiyegunle, while low values of $\mathrm{Z}_{\mathrm{b}}$ are observed around Garaku and Katakwa . 


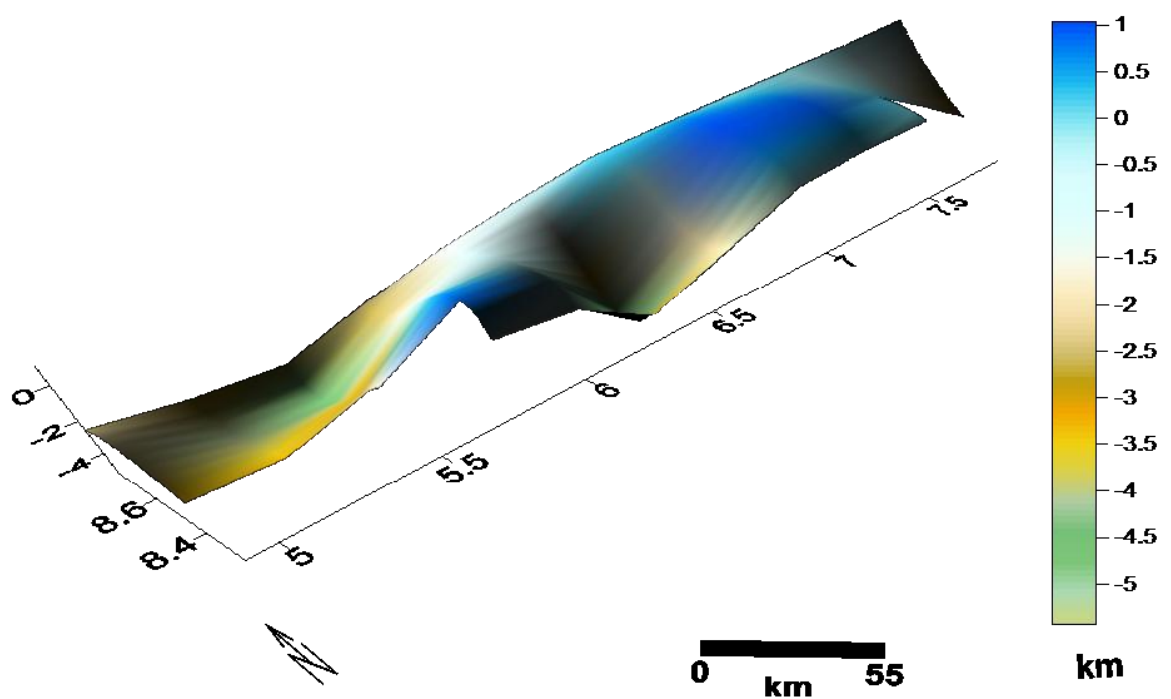

Fig. 8: Surface relief map of fractal depth-to-top of magnetic sources $\left(\mathrm{z}_{\mathrm{t}}\right)$.

Table 3: Summary of the results obtained for $\mathrm{Z}_{\mathrm{b}}, \Delta \mathrm{z}$ and $\mathrm{Q}$

\begin{tabular}{|c|c|c|c|c|}
\hline $\begin{array}{c}\text { Longitude } \\
\text { (Decimal degrees) }\end{array}$ & $\begin{array}{c}\text { Latitude } \\
\text { (Decimal } \\
\text { degrees) }\end{array}$ & $\mathrm{Z}_{\mathrm{b}}(\mathrm{km})$ & $\Delta \mathrm{z}(\mathrm{km})$ & $\begin{array}{l}\text { Geothermal heat flow (Q) } \\
\qquad\left(\mathrm{mW} / \mathrm{m}^{2}\right)\end{array}$ \\
\hline 4.625 & 8.750 & No data & No data & No data \\
\hline 4.905 & 8.750 & 15.044 & 12.534 & 69.396 \\
\hline 5.125 & 8.750 & 14.520 & 11.120 & 71.901 \\
\hline 5.375 & 8.750 & 14.600 & 12.452 & 71.507 \\
\hline 5.625 & 8.750 & 15.094 & 11.652 & 69.167 \\
\hline 5.875 & 8.750 & 12.494 & 10.874 & 83.560 \\
\hline 6.125 & 8.750 & 10.092 & 9.072 & 103.448 \\
\hline 6.375 & 8.750 & 11.801 & 11.233 & 88.467 \\
\hline 6.625 & 8.750 & 10.929 & 10.844 & 95.526 \\
\hline 6.875 & 8.750 & 10.329 & 10.291 & 101.075 \\
\hline 7.125 & 8.750 & 11.672 & 11.628 & 89.445 \\
\hline 7.375 & 8.750 & 10.316 & 10.240 & 101.202 \\
\hline 7.625 & 8.750 & 10.640 & 10.526 & 98.120 \\
\hline 7.875 & 8.750 & 8.364 & 8.298 & 124.821 \\
\hline 5.625 & 8.250 & 11.030 & 10.405 & 94.651 \\
\hline 5.875 & 8.250 & 12.485 & 11.241 & 83.620 \\
\hline 6.125 & 8.250 & 14.778 & 11.063 & 70.646 \\
\hline 6.375 & 8.250 & 13.418 & 9.950 & 77.806 \\
\hline 6.625 & 8.250 & 12.688 & 10.868 & 82.283 \\
\hline 6.875 & 8.250 & 9.070 & 8.845 & 115.105 \\
\hline 7.125 & 8.250 & 10.214 & 10.192 & 102.213 \\
\hline 7.375 & 8.250 & 8.986 & 8.895 & 116.181 \\
\hline
\end{tabular}

Geothermal heat flow: The geothermal heat flow values range from $69.167 \mathrm{mWm}^{-2}$ to $124.821 \mathrm{mWm}^{-2}$ with an average value of $90.959 \mathrm{mWm}^{-2}$. Figure 10 indicates high values of Q around Kuje, Garaku, Katakwa, Keffi and Baro; while low values of Q occur around Pategi, Share, Lafiagi and Aiyegunle areas.

Thorium (Th) content map: Figure 11 is the thorium content map of the study area. The map shows high concentration of Th around Isanlu and Kuje. Low concentration of Th is predominant around Garaku and Ndegi.

Potassium (K) content map: Figure 12 is the potassium content map of the study area. The map shows high concentration of K around Isanlu, Share, Aiyegunle, Lafiagi, Ndegi and Keffi. Low concentration of K is prevalent around Gulu, Katakwa and Koton Karifi.

Uranium (U) content map: Figure 13 is the uranium content map of the survey area. The map shows high concentration of U around Isanlu, Gulu and Katakwa. Low concentration of U is prevalent around Pategi, Aiyegunle and Lafiagi. 


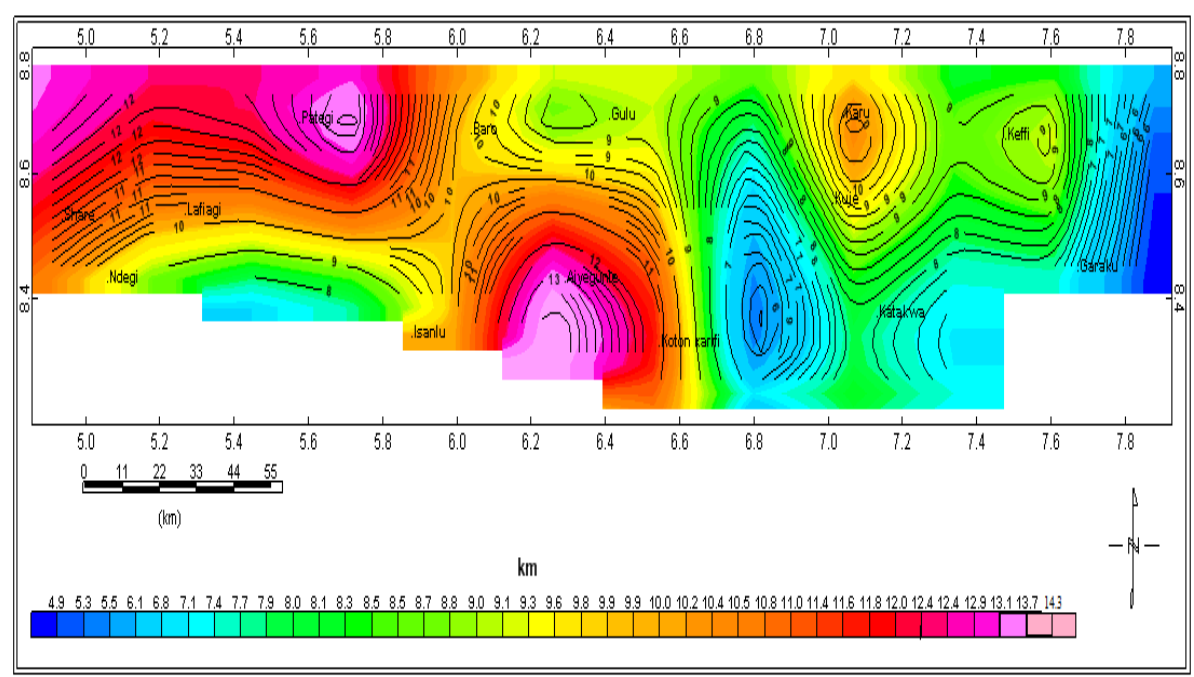

Fig. 9: Fractal depth-to-bottom of magnetic sources. Contour interval $=0.5 \mathrm{~km}$.

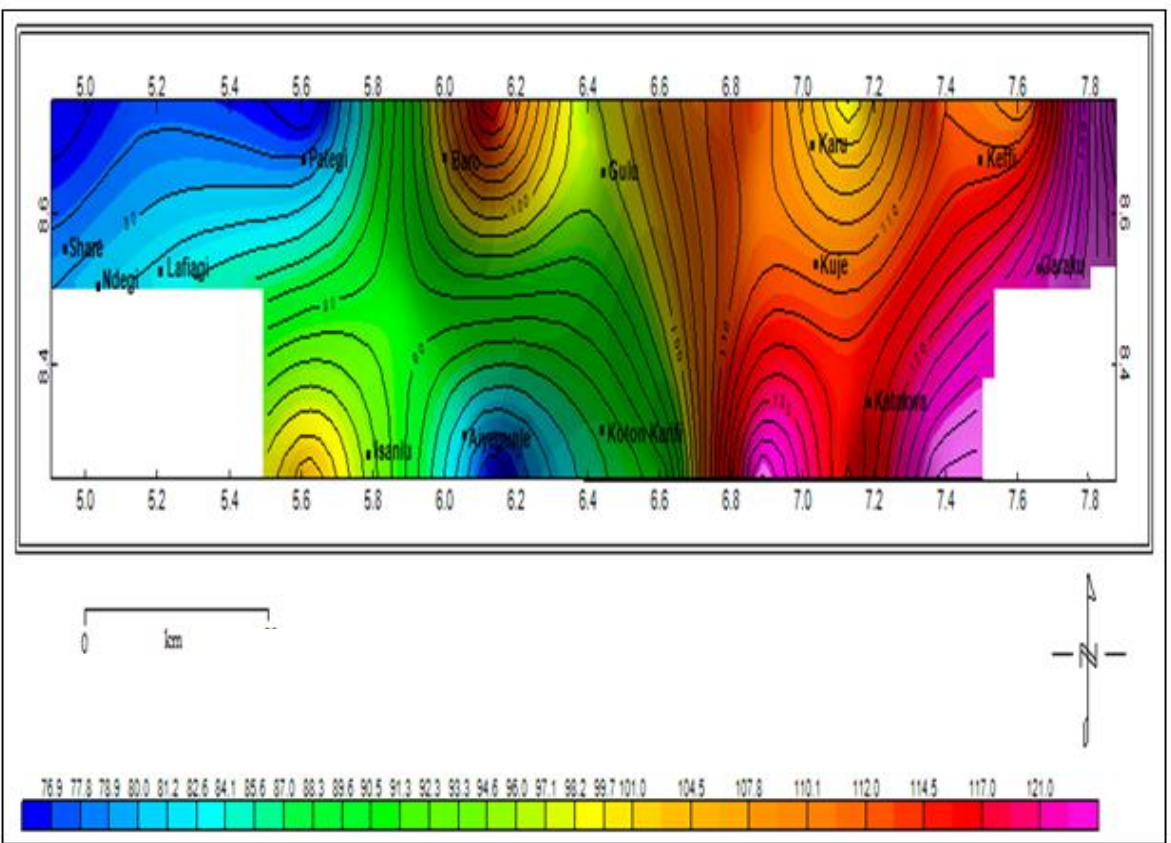

Fig. 10: Geothermal heat flow. Contour interval $=10 \mathrm{mWm}^{-2}$

Radioactive heat analysis: The result of the radioactive heat analysis is shown in Table 4. The radioactive heat values range from 0.91 to $4.53 \mu \mathrm{W} / \mathrm{m}^{3}$ with an average value of $2.28 \mu \mathrm{W} / \mathrm{m}^{3}$. The radioactive heat map Figure 14 shows high radioactive heat values at Katakwa, Kuje, Karu, Isanlu, Lafiagi and Ndegi. While low radioactive heat values are observed at Aiyegunle, Koton Karifi, Pategi, Baro, Share, Keffi and Garaku. 


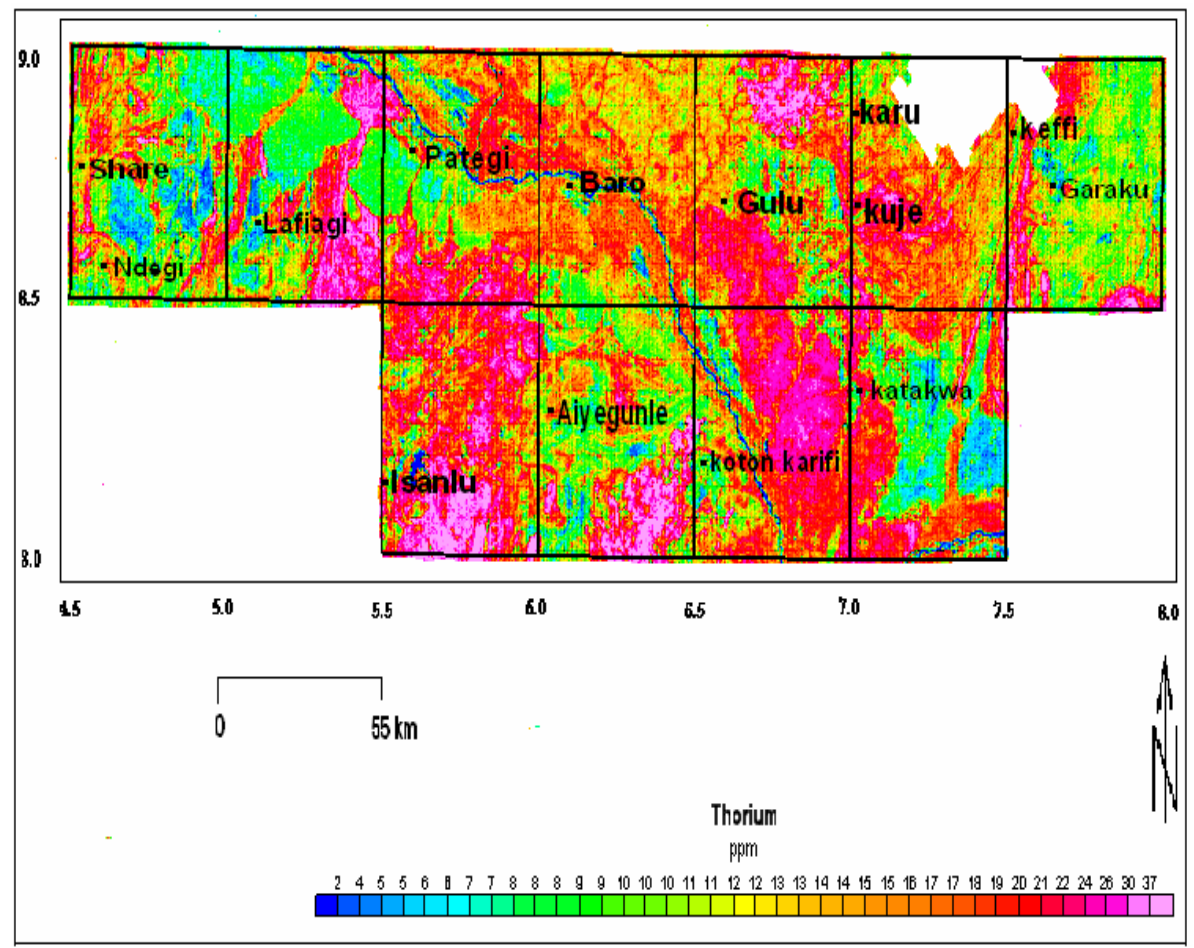

Fig. 11: Thorium content

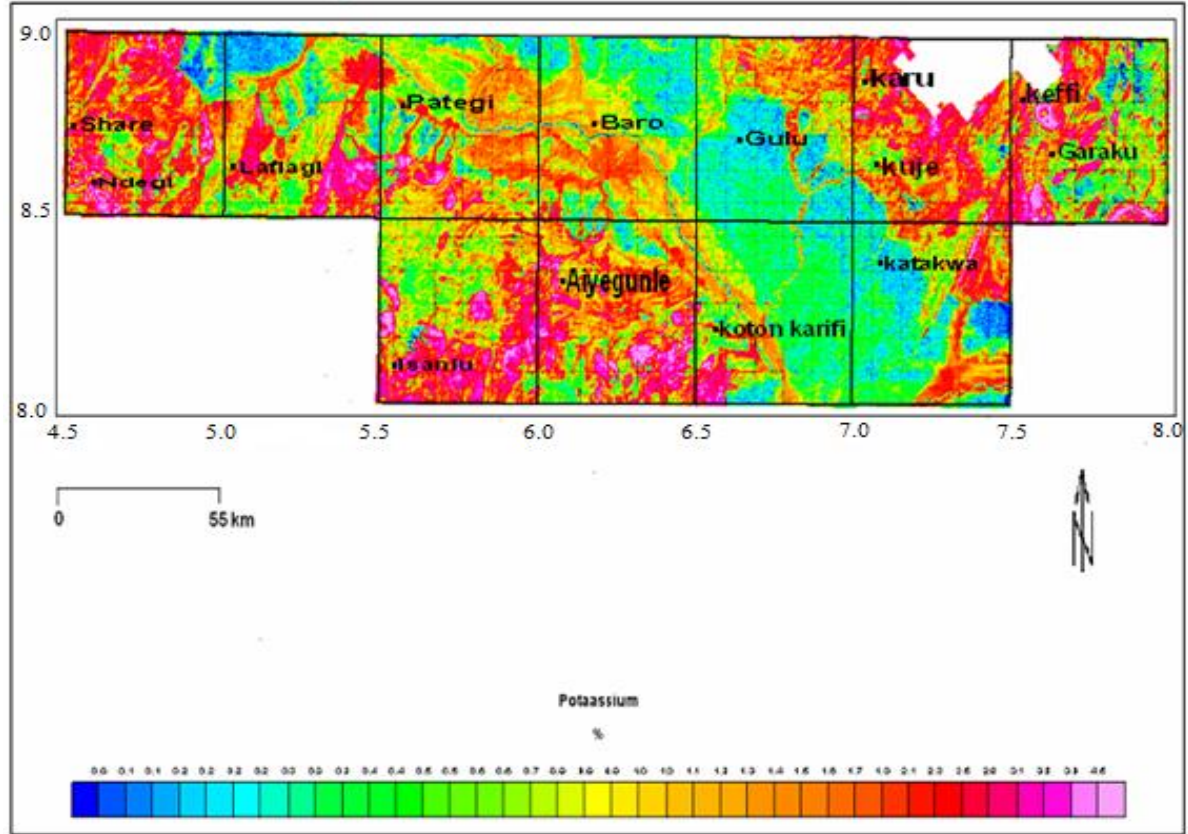

Fig. 12: potassium content 


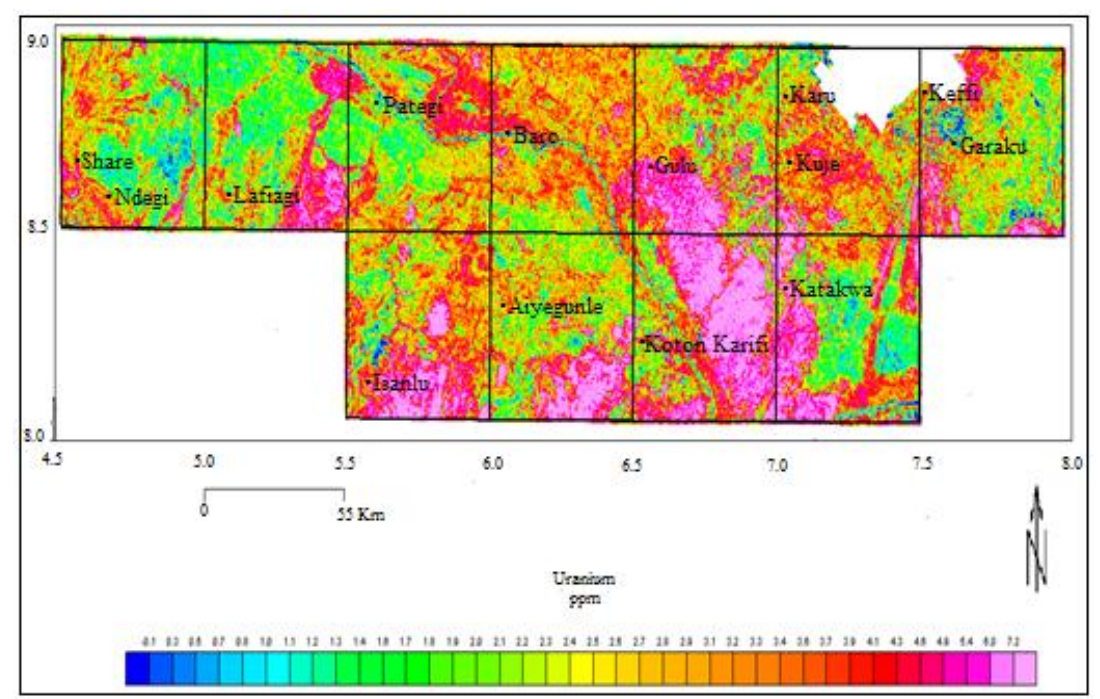

Fig. 13 uranium content

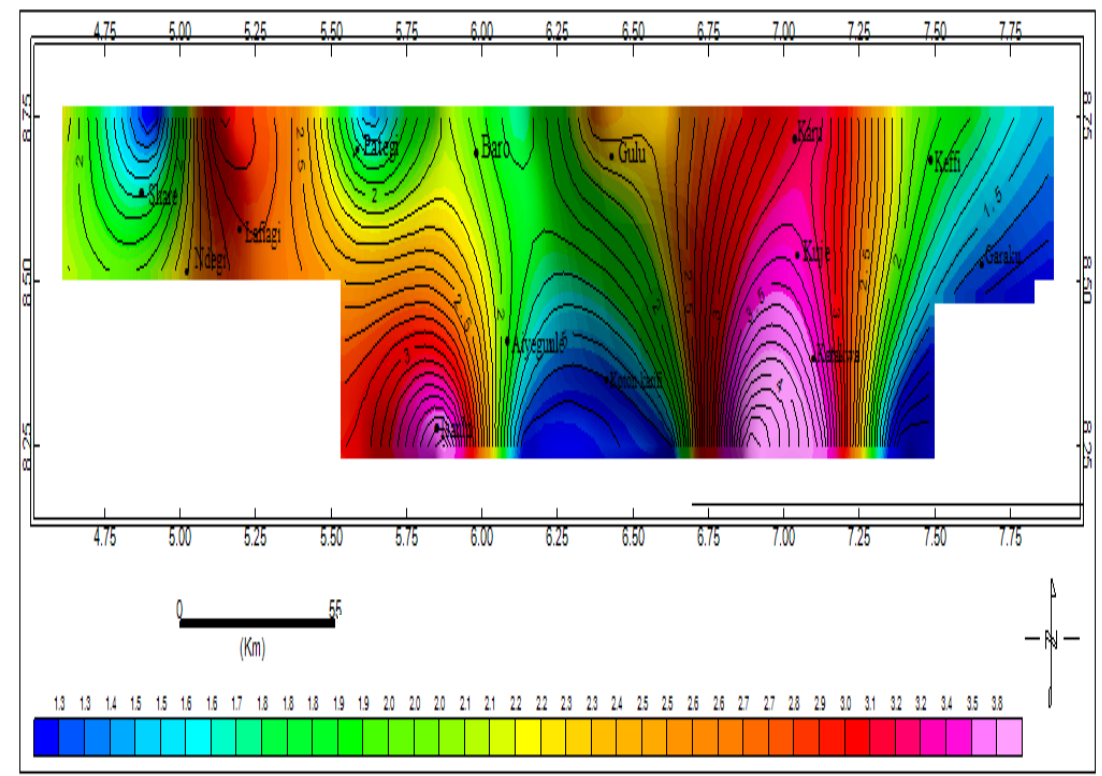

Fig.14: Radioactive heat

\section{Discussion and conclusion}

\subsection{Discussion}

Geothermal heat analysis:-Geothermal heat flow of about $124.821 \mathrm{mWm}^{-2}$ was observed around Garaku, situated in the northeastern section of the study area, where the basal depth is shallow and the heat source may be close to the surface. The Garaku area also has occurrence of biotite-granite gneiss rocks, which are associated with magnetic mineralization (Figure 2). The biotite-granite gneiss rock exhibits high heat conductivity.

Correlation of the radioactive heat and geothermal heat flow maps (Katakwa High):

Correlation of both maps shows high radioactive heat values corresponding to high geothermal heat flow values at Katakwa (Figure 15). The radioactive heat and geothermal heat flow values at the Katakwa area are $3.75 \mu \mathrm{W} / \mathrm{m}^{3}$ and $102.213 \mathrm{~mW} / \mathrm{m}^{2}$ respectively. 


\subsection{Conclusion}

Magnetic high anomalies were observed around Garaku, Katakwa and Koton Karifi areas where there are occurrences of iron ore. Additionally, magnetic high anomalies were observed around Ndegi, Gulu, Garaku and Keffi sections where there are occurrences of biotite granite rocks. Furthermore, Gulu and Katakwa have occurrence of granite rocks. These rocks are associated with thorium and uranium mineralization. Potassium occurrence is also high around Aiyegunle. The Aiyegunle area has occurrence of shales, sandstones and feldspar which are associated with high potassium-activity.

The highest sediment thickness was observed around Lafiagi (north-western section of the survey area) with a value of about $3.88 \mathrm{~km}$. This thickness may enhance the accumulation of hydrocarbons. In addition, the units that comprise high heat flow values correspond with radioactive regions since this unit may have high heat conductivities. Thus, Katakwa is suggested as an anomalous geothermal heat area, based on the correlation of high geothermal heat flow with radioactive heat.

Table 4: Summary of the result for radioactive heat analysis

\begin{tabular}{|c|c|c|c|c|c|}
\hline Subsection & $\begin{array}{c}\text { Longitude } \\
\text { (Decimal } \\
\text { Degrees) }\end{array}$ & $\begin{array}{l}\text { Latitude } \\
\text { (Decimal } \\
\text { Degrees) }\end{array}$ & Rock Type & $\begin{array}{l}\text { Average Density } \\
\left(\mathrm{g} / \mathrm{cm}^{3}\right)\end{array}$ & $\begin{array}{l}\text { Radioactive Heat } \\
\left(\mu \mathrm{W} / \mathrm{m}^{3}\right)\end{array}$ \\
\hline 1 & 4.625 & 8.75 & Schist & 2.64 & 2.138 \\
\hline 2 & 4.905 & 8.75 & Biotite granite & 2.64 & 1.141 \\
\hline 3 & 5.125 & 8.75 & Sandstone & 2.35 & 2.950 \\
\hline 4 & 5.375 & 8.75 & Sandstone & 2.35 & 2.600 \\
\hline 5 & 5.625 & 8.75 & Sandstone & 2.35 & 1.382 \\
\hline 6 & 5.875 & 8.75 & Sandstone & 2.35 & 2.124 \\
\hline 7 & 6.125 & 8.75 & Sandstone & 2.35 & 1.690 \\
\hline 8 & 6.375 & 8.75 & Migmatite & 2.74 & 2.395 \\
\hline 9 & 6.625 & 8.75 & Biotite granite & 2.64 & 2.337 \\
\hline 10 & 6.875 & 8.75 & Migmatite & 2.74 & 2.819 \\
\hline 11 & 7.125 & 8.75 & Migmatite & 2.74 & 3.232 \\
\hline 12 & 7.375 & 8.75 & Migmatite & 2.74 & 2.127 \\
\hline 13 & 7.625 & 8.75 & Biotite granite & 2.64 & 1.794 \\
\hline 14 & 7.875 & 8.75 & Granodiorite & 2.73 & 1.481 \\
\hline 15 & 5.625 & 8.25 & Biotite granite & 2.64 & 2.974 \\
\hline 16 & 5.875 & 8.25 & Schist & 2.64 & 3.929 \\
\hline 17 & 6.125 & 8.25 & Sandstone & 2.35 & 1.247 \\
\hline 18 & 6.375 & 8.25 & Sandstone & 2.35 & 1.261 \\
\hline 19 & 6.625 & 8.25 & Sandstone & 2.35 & 1.367 \\
\hline 20 & 6.875 & 8.25 & Migmatite & 2.74 & 4.531 \\
\hline 21 & 7.125 & 8.25 & Migmatite & 2.74 & 3.750 \\
\hline 22 & 7.375 & 8.25 & Granodiorite & 2.73 & 0.907 \\
\hline
\end{tabular}




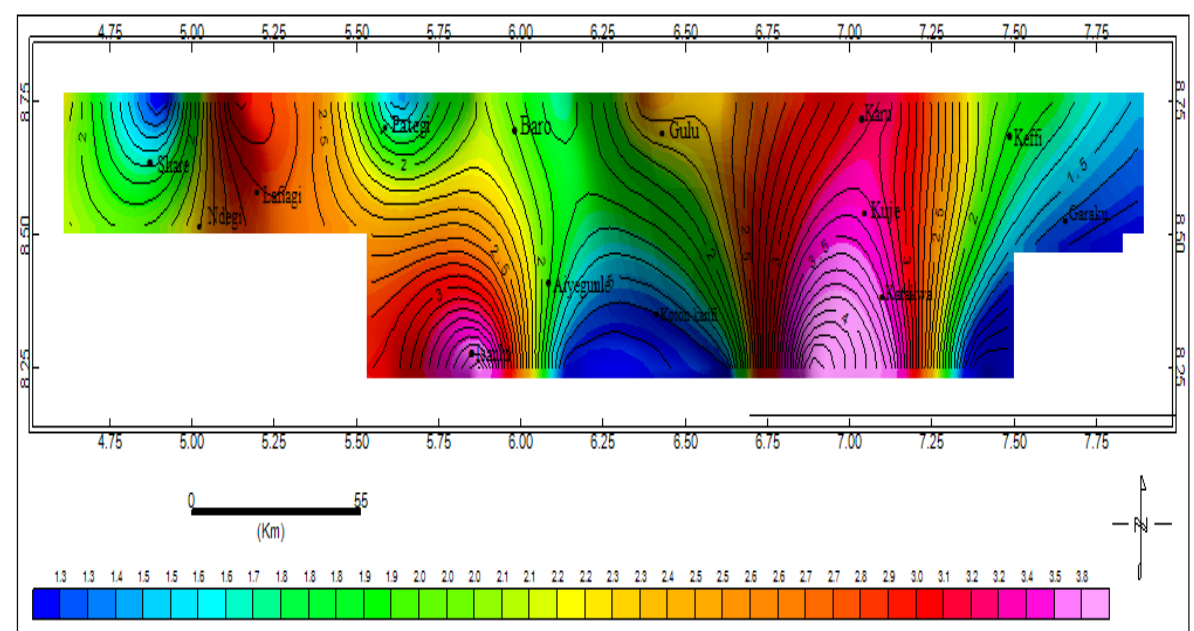

(a) Radioactive heat map
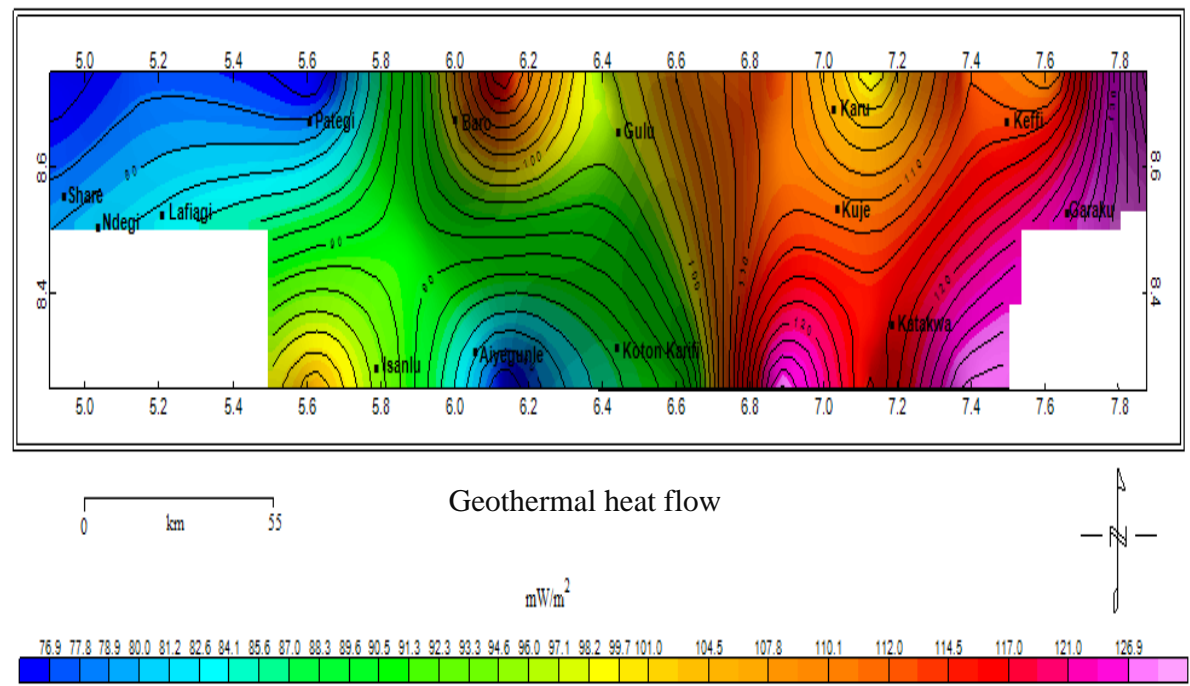

(b) Geothermal heat flow map

Fig. 15:Correlation of (a) radioactive heat and (b) geothermal heat flow maps

\section{Acknowledgements}

The authors are grateful to the staff of Physics Department, Federal University of Technology, Minna and the staff of the Nigerian Geological Survey Agency, Kaduna, Nigeria for their invaluable assistance in various capacities.

\section{References}

[1] Akande, S. O., Ojo, O. J., Erdtmann, B. D. \& Hetenyi, M. Paleoenvironments, organic petrology and rock-eval studies on source rock facies of the Lower Maastrichtian Patti Formation, southern Bida Basin, Nigeria. Journal of African Earth sciences, Vol. 41, (2005). pp. $394-406$.

[2] Bansal, A. R. \& Dimri, V. P. Depth determination from a non- stationary magnetic profile for scaling geology. Geophysical Prospecting, Vol. 53, (2005). pp. 399-410.

[3] Björnson, S., Gudmundsdottir, I. D. \& Kettilsson, J. Geothermal development and research in Iceland. Iceland: Okustofnun Press, (2010). pp.1-40.

[4] Blakely, R. J. Curie temperature isotherm analysis and tectonic implications of aeromagnetic data from Nevada. Journal of Geophysics Research, Vol. 93, (1988). pp.11, 817-11,832.

[5] Braide, S. P. Sedimentation and tectonics in the southern Bida Basin, Nigeria. depositional response to varying tectonic context. American Association of Petroleum Geologists (AAPG) Bulletin, Vol. 74, (1990). pp. 1-20.

[6] Bouligand, C., Jonathan, M., Glen, G. \& Blakely, R. J. Mapping Curie temperature depth in the western United States with a fractal model for crustal magnetization. Journal of Geophysical Research, Vol. 114, (2009). pp. 1-25.

[7] Connard, G., Couch, R. \& Gemperle, M. Analysis of aeromagnetic measurements positional from the Cascade Range in central Oregon. Geophysics, Vol. 48, (1983). pp. 376-390. 
[8] Dimri, V. P. Fractal detectability limits of geophysical surveys. Geophysics, Vol. 2, (1998). pp.1943-1946.

[9] Fedi, M., Quarta, T. \& Santis, A. D. Inherent power law behaviour spectra from a Spector and Grant ensemble. Geophysics, (1997). pp. 11431150 .

[10] Gettings, M. E. Multifractal magnetic susceptibility distribution models of hydrothermally altered rocks in the Needle Creek Igneous Center of the Absaroka Mountains, Wyoming, Nonlinear Processes. Geophysics, Vol. 12, (2005). pp. 587-601.

[11] Gragnon, J. S., Lovejoy, S.\& Schertzer, D. Multifractal surfaces and terrestrial topography. Europhysics Letters, Vol. 62, (2003). pp. 801807.

[12] Hahn, A., Kind, E. G. \& Mishra, D. C. Depth estimation of magnetic sources by means of Fourier amplitude spectra. Geophysics, Vol. 24, (1976). pp. 287-308.

[13] Lawal, K. M., Umego, M. N. \& Ojo, S. B. Depth to basement mapping using Fractal technique: application to the Chad Basin, northeastern Nigeria. Nigerian Journal of Physics, (2007). pp.75-88.

[14] Lovejoy, S., Pecknold, S. \& Schertzer, D. Stratified multifractal magnetization and surface geomagnetic fields-I: Spectral analysis and modeling. Geophysical Journal International, Vol. 145, (2001). pp.112-126.

[15] Maus, S. \& Dimri, V. P. Scaling exponents of potential fields due to scaling Sources. Geophysics Research Letters, Vol. 21, (1994). pp. 89894.

[16] Maus, S. \& Dimri, V. P. Potential field power spectrum inversion for scaling Geology. Journal of Geophysics Research, Vol. 100, (1995). pp.12605-12616.

[17] Maus, S. \& Dimri, V. P. Depth estimation from the scaling power of potential fields. Geophysical Journal International, Vol. 124, (1996).pp. $113-120$.

[18] Maus, S., Gordon, D. \& Fairhead, D. Curie temperature depth estimation using a self-similar magnetization model. Geophysical Journal International, Vol. 129, (1997). pp. 163- 168.

[19] Müjgan, S., Oya, P. \& Ilknur, K. Determination of the Curie Point Depth and Heat Flow from Magsat Data of Western Anatolia. Journal of Balkan Geophysical Society, Vol. 8, (2005). pp. 149-160.

[20] Nwankwo, L. I., Olasehinde, P. I. \& Akoshile, C. O. Spectral analysis of aeromagnetic anomalies of the northern Nupe Basin, west central, Nigeria. Global Journal of Pure and Applied Sciences, Vol. 14, (2008). pp. 247-252.

[21] Nwankwo, L. I., Olasehinde, P. I. \& Akoshile, C. O. Heat flow Anomalies from Spectral analysis of aeromagnetic data of Nupe Basin, Nigeria. Asian Journal of Earth Sciences, (2011). pp. 1- 7.

[22] Obaje, N. G. Geology and mineral resources of Nigeria. Berlin: Springer Publishers, (2009). pp. 1-203.

[23] Pecknold, S., Lovejoy, S. \& Schertzer, D. Stratified multifractal magnetization and surface geomagnetic fields. Multifractal analysis and simulations. Geophysical Journal International, Vol. 145, (2001). pp. 127-144.

[24] Pilkington, M., Gregotski, M. E. \& Todoeshcuck, J. P.Using fractal crustal magnetization models in magnetic interpretation. Geophysical prospecting Vol. 42, (1994). pp. 677-692.

[25] Pilkington, M. \& Todoeshcuck, J. P. Stochastic inversion for scaling geology. Geophysical Journal International, Vol. 102, (1990). pp. 205217.

[26] Pilkington, M \& Todoeshcuck, J. P. Use of fractals in potential field interpretation. Canadian Geophysical Society, (1998). pp. 1-2.

[27] Ravat, D., Pignatelli, A. Nicolosi, I. \& Chiappini, M. A study of spectral methods of estimating the depth to the bottom of magnetic sources from near-surface magnetic anomaly data. Geophysical Journal International, Vol. 169, (2007). pp. 421-434.

[28] Ross, H. E., Blakely, R. J. \& Zoback, M. D. Testing the use of aeromagnetic data for the determination of Curie depth in California. Geophysics, Vol. 71, (2006). pp. 10-16.

[29] Salem, A. \& Fairhead, D. Geothermal reconnaissance of Gebel Duwi area, Northern Red Sea, Egypt using airborne magnetic and spectral gamma ray data. Getech (2011). pp.1-22.

[30] Shekwolo, P. D. Regional hydrogeology of Bida Basin, Ph.D. Thesis, Ahmadu Bello University, Zaria, Nigeria. (1992).

[31] Stacey, F. D. Physics of the Earth. New York: John Wiley and Sons, (1977). pp. 1-416.

[32] Spector, A. \& Grant, F. S. Statistical models for interpreting aeromagnetic data. Geophysics, Vol. 35, (1970). pp. $293-302$.

[33] Sunmonu, L. A. \& Dimri, V. P. Multifractal analysis and seismicity of the Himalayan Region-a case study. Nigerian Journal of Physics, Vol. 13, (2001). pp. 106-111.

[34] Tanaka, A., Okubo, Y. and Matsubayashi, O. Curie point depth based on spectrum analysis of the magnetic anomaly data in East and Southeast Asia. Tectonophysics, Vol. 306, (1999). pp. 461-470.

[35] Telford, W. M., Geldart, L. P., Sherif, R. E. \& Keys, D. A. Applied Geophysics. Cambridge: Cambridge University Press. (1990).

[36] Todoeshcuck, J. P., Pilkington, M. \& Gregotski, M. E. If geology is fractal, what do we do? The Leading Edge, (1992). pp. 29-35.

[37] Turcotte, D. L. Fractals and chaos in geology and geophysics. New York: Cambridge University Press. (1992). 